\title{
Nondestructive micromagnetic evaluation of surface damage after grinding
}

Mária Čilliková, Marián Mičúch, Miroslav Neslušan, Anna Mičietová

University of Žilina, Faculty of Mechanical Engineering, Department of Machining and Manufacturing Engineering, Univerzitná 1, 010 26, Slovak Republic, maria.cillikova@fstroj.uniza.sk

This paper deals with investigation of surface damage induced by grinding operation as a result of dry grinding through micromagnetic technique based on Barkhausen noise. This study presents information about wet and dry grinding and associated surface integrity expressed in such term as residual stresses, structure alterations beneath the ground surface and corresponding magnetoelastic responses. Lack of coolant or insufficient coolant supply can be found as a reason of surface burn during grinding. Therefore, this paper compare magnetoeslatic responses of surface obtained during wet and dry grinding. Results of experiment indicate that properly suggested monitoring system can reliably detect surface burn induced by thermal overload of ground surface.

Key words: Barkhausen noise, grinding, coolant

\section{Acknowledgment}

This project is solved under the financial support of VEGA agency (project n. 1/0097/12 and n. 1/0223/11) and KEGA agency (project n. 023TUKE-4/2012 and 031ŽU-4/2011).

\section{References}

[1] KARPUCHEWSKI, B. (2002). Introduction to Micromagnetic Techniques, ICBN 01, Hannover.

[2] ALTPETER, I. , THEINER W., BECKER, R. (1981). Eigenspannungsmessung an stal deer Güte 22 NiMoCr 37 mit mag-netischen und magnetoelastischen Prüfverfahren, In: 4th Intern.Conf.on NDE in Nuclear Industry, Lindau.

[3] MATSUMOTO, Y., HASHIMOTO, F., LAHOTI, G. (1999). Surface Integrity Generated by Precision Hard Turning, In: CIRP Annals, 48/1/1999, p. 59-82.

[4] BRANDT, D. (1995). Randzonenbeeinflussung beim Hartdrehen, Dr.-Ing. Dissertation, Universität-Hannover.

[5] HASHIMOTO, F., GUO, Y., WAREN, A.W.(2006). Surface Integrity Difference between Hard Turned and Ground Surfaces and its Impact on Fatigue Life, CIRP Annals, 55/1/2006, p. 81 - 84.

[6] SORSA, A., LEVISKA, K., SANTA AHO, S., LEPISTO, T.(2012). Quantitative Prediction of Residual Stresses and Hardness in Case-hardened Steel based on the Barkhausen Noise Measurement, NDT and E, Vol. 46, p. 100106.

[7] MOORTHY, V., SHAW. B.A., BRIMBLE, K., ATKINS, I.(2001). Evaluation of Heat Treatment and Deformation Induced Changes in Material Properties in Gear Steels using Magnetic Barkhausen Noise Analysis, In: ICBN 03, Finland, pp. $1-20$.

[8] NESLUŠAN, M., ROSIPAL, M., KOLǍ̌ÍK, K., OCHODEK, V. (2012). Application of Barkhausen Noise for Analysis of Surface Integrity after Hard Turning, In: Manufacturing technology, Vol. 12, p. 60-65.

[9] NESLUŠAN, M., ROSIPAL, M., OCHODEK, V. (2011). Analysis of Some Aspects of Surface Integrity after Grinding and Hard Turning trough Barkhausen Noise, In: ICBN 09, Czech Republic.

[10] NOVÁK, M. (2012). Surfaces with High Precision of Roughness after Grinding. In: Manufacturing technology, Vol. 12, pp.66-70.

[11] HOLEŠOVSKÝ, F., NÁPRSTKOVÁ, N., NOVÁK, M., (2012). GICS for griding process optimization. In: Manufacturing technology, Vol. 12, pp.22-26.

[12] VARGA, G., KUNDRÁK, J. (2013). Effect of Environmentally Conscious Machining on Machined Surface Quality, In: Applied Mechanics and Materials, Vol. 309, pp. 35-42. 